\title{
Efficiency Analysis of National Essential Technological Strength
}

\author{
Shu-Hao Chang \\ Associate researcher, Science \& Technology Policy Research and Information Center \\ National Applied Research Laboratories \\ Taiwan, Province of China
}

Chin-Yuan Fan

Associate researcher, Science \& Technology Policy Research and Information Center National Applied Research Laboratories

Taiwan, Province of China

$\begin{array}{lrr}\text { Received: May 11, } 2015 & \text { Accepted: June 4, } 2015 \quad \text { Published: July 1, } 2015 \\ \text { doi:10.5296/jmr.v7i4.7588 } & \text { URL: http://dx.doi.org/10.5296/jmr.v7i4.7588 }\end{array}$

\begin{abstract}
The innovative capacity of national technology possesses crucial status in the process of technological development. Constant innovation is required to facilitate national competitiveness. Although numerous studies have indicated the importance of technological innovation, few have focused on the national essential technological strength. The current study determined the national essential technological strength in various countries from the perspective of patent analysis. In addition, we investigated the research and development efficiencies of quality technology strengths in various countries to provide a reference and recommendation for the government. In this study, we adopted the data envelopment analysis method for analyzing the national essential technological strengths and efficiencies of the major patent countries and analyzed the variations in interperiod efficiencies and total factor productivities of various countries to oversee the dynamic changes. The results indicated that the United States, Singapore, Taiwan, and China exhibited satisfactory strengths and efficiencies in national essential technological strength, and those of China have grown substantially in recent years.
\end{abstract}

Keywords: Essential technological strength, Data envelopment analysis, Patent analysis, Efficiency analysis, National innovation strength 


\section{Introduction}

Intellectual properties can be interpreted as the fruit of human wisdom, result of creation, and specifically, intangible product generated from the activities of creation based on human ideas. Patent right is one of the rights of intellectual properties. In addition to protecting the legal effectiveness of patentees' inventions, patent rights are considered as an indicator for measuring the research and development $(R \& D)$ energy of technological innovation within a country, region, enterprise, or organization. Along with the arrival of the knowledge economy, crucial economies worldwide have begun emphasizing economic values generated from intangible assets. The values derived from the intellectual properties have become a key factor of economic growth (Laitner and Stolyarov, 2013). Increasing numbers of manufacturers have invested more capital on intangible assets than on physical assets. This change has also been reflected on various national economic and systematic reforms in the recent years. Among the intangible assets, patents are most capable of generating noticeable interests and revenues for enterprises. Numerous transnational research institutes and companies use patent statistics and analyses as crucial indicators for measuring the R\&D energy of nations and enterprises (Faber and Hesen, 2004; Narin, 1995; Schmoch, 1999).

Therefore, researchers and policymakers have used patent literature data to analyze the growth and development of technological innovation in the recent years (Holgersson, 2013; OECD, 2009; Park and Yoon, 2014; Sternitzke, 2009). In contrast to other technological indicators, such as R\&D personnel and funding, patent data can provide unique and detailed information on invention activities. Patent analysis has progressively gained substantial attention; for example, Griliches (1990) used patent data for evaluating economic power in his paper, which has become a classic study. Thus, this reflected the common application of patent statistical data in academia. In another example, in 1994, the Organization for Economic Co-operation and Development (OECD) first published the Patent Manual in which immense statistical data was used for monitoring patent application activities (OECD, 1994). A number of companies even achieved substantial development by selling commercial patent intelligence by using these statistical methods. Moreover, an increasing number of patent data can be obtained electronically from databases such as the United States Patent and Trademark Office.

Previous studies constitute a diverse research base regarding patent analysis (i.e., technological performance of specific and emerging domains [Chen et al., 2013; Lei et al., 2013], diffusion of knowledge and evolution of dynamic technologies [Kumazawa and Gomis-Porqueras, 2012; Park et al., 2012], and economic values of inventions [Griliches, 1990; Pakes, 1986]). In addition, patent application conditions in the past can be used to predict prospective patent application conditions of specific nations, institutions, and companies (OECD, 2009). Nevertheless, few analyses of the R\&D efficiencies of various nations from the perspective of patents have been performed. Specifically, no relevant studies have used the strength of national quality technology as the output variable for determining R\&D efficiencies. The numbers of patents and referred patents have mostly been used as measuring indicators for patent R\&D output variables (Wu and Tseng, 2006). However, these methods of measurement comprised possible errors, such as the size of nations and 
consistency of patent qualities. Thus, this study adopted the relative national essential technological strength indicator as an output variable for measuring the R\&D efficiencies of nations.

This study determined the technological strengths of various nations by using patent analysis primarily through statistical analysis and comparison of various information related to patent documents. The results were presented as graphical information and intelligence to provide policymakers with a basis for investigating the statuses of technological development in various nations. The investigations involved adopting various patent analysis models. First, we analyzed the overall granted patent trend in various nations to determine the patent development statuses of various nations. Second, we determined the impact exerted by the major patent nations. By using calculating indicators, we determined the impact of various major patent nations and indicated the advantageous technological strengths of these nations. Finally, we used the data envelopment analysis (DEA) method for investigating the patent $R \& D$ efficiencies of various nations.

\section{Literature Review}

\subsection{Patent Data and Technological Activities}

Patent making is a means for protecting enterprise, institutional, or personal inventions or creations; thus, patents can be used as indicators of invention. Patent indicators can be used for communicating information on the processes and results of inventive or creative activities. Numerous studies have indicated that patent quantities are related to other performance indicators (i.e., productivity or market value) (Chen et al., 2013; Fung, 2005; Hall et al., 2005). Statistical studies on patent data can provide unique insights into innovative processes, particularly for providing relevant information on the geographic positions of technological domains and inventions.

Another major advantage of patent data is to obtain extensive technological development information at relatively low costs. Patent databases have been prepared by patent offices for auditing patents and managing information communications. These databases have been initially created for internal use by the patent office. Currently, patent data is open for public access on the Internet. The reduction of computer costs in recent years has enabled large scale and easy public accessibility to these data. Nevertheless, patent indicators are flawed; not all inventions become patented. Companies can select other means to keep their information confidential or rely on other mechanisms to obtain a leading edge in the market; thus, patent data must be used cautiously. In addition, only a few patents consist of extremely advanced technologies and economic value, and numerous patents never find applications. Therefore, individual patent quality varies dramatically (Cheng et al., 2010; Lanjouw and Schankerman, 2004). Simply conducting a patent count with equal patent weighting can be misleading, particularly on a small sample size.

Finally, current technological development can be determined using published literature, technologically relevant conference papers, and patent data. Patents have the benefit of protecting R\&D accomplishments; thus, enterprises tend to publish research 
accomplishments using patents. In addition, researchers and enterprises can shorten the funding and research period by exploiting patent information (Narin, 1995; Narin et al., 1997). Information provided by patents can be used to identify the technological information of competitors and effectively allocate R\&D resources. A nation's patents represent its technological type and advantage. Patent analysis can be used to determine technological expertise and history and activities associated with the technological development of various nations (OECD, 2009).

\subsection{Timing and Process of Patent Analyses}

Patent analysis refers to the process of organizing various patent-related data by using statistical methods into graphical information that can be analyzed and interpreted. Patent data are the raw documents of patents and are open data (i.e., patent specification and patent gazette). Patent analysis can convert fragmented patent data into systematic and valuable patent knowledge. Patent analysis can be considered an effective tool for planning technological R\&D and managing intellectual property rights as well as a basis for analyzing technological competitions and overall development directions (Hall et al., 1986). Regarding patent analysis studies, some examples include comparing catch-up modes in technological innovations of various nations (Wang and Tsai, 2010), evaluating the centrality and betweenness characteristic of technological networks to plan national R\&D directions and strategies (Park and Yoon, 2014), or measuring the innovative capacities of nations (Faber and Hesen, 2004). The aforementioned studies have attempted to determine the overall directions of technological development and innovative capacities of various nations by applying quantitative methods (which refers to using various statistical techniques for resolving output data and relevant literature information for determining the technological status and overall prospective development direction). Patents are audited and obtained from authorities, such as national patent offices, who make announcements following legal procedures. Thus, the credibility and reliability of the statistical information are comparatively high.

To nations and industries, analysis based on patent information provides a crucial tool of reference in R\&D processes. For example, analyzing the reference literature of tens of thousands of data from the patent database can determine the overall or key development direction of a nation or industry. In addition, enterprises can analyze their competitiveness by applying these analysis methods. However, this represents only one of the values of patent analysis. When elements in the patent information (i.e., patentee, nations, era, and referenced literature) are cross-tabulated, the results provide a firm ground for the competitiveness of nations, industries, and enterprises. Patent data are raw patent documents and must be converted to patent information by performing patent analysis, which subsequently converts patent data into patent intelligence. Nations and industries can then access these processes and results in records to formulate technological development strategies.

From a national or industrial perspective, patent timing can be divided into strategic and tactical levels. Regarding strategies, when nations plan to become involved in an emerging industry, they can use the patent database to determine the technological status and 


\section{MlMacrothink}

Journal of Management Research

ISSN 1941-899X

2015, Vol. 7, No. 4

prospective development direction of the industry, and by performing competitor analysis, these nations can determine their technological gap with other nations for subsequent patent protfolio, market development, and resource searching. Regarding the tactical level, nations can trace specific products prior to product development for determining and analyzing the patents and technologies of competitor products to prevent being drawn into patent ambush in subsequent product development processes. Table 1 shows the applications of patent analysis in nations and industries.

Table 1. National and industrial applications of patent analysis

\begin{tabular}{|c|c|}
\hline Application items & Researchers \\
\hline $\begin{array}{l}\text { The evaluation of the patents' economic values toward the } \\
\text { assignees and the rewards generated by innovation: Patent } \\
\text { ownership yields high rewards and potential market sizes }\end{array}$ & $\begin{array}{l}\text { Ernst (1995); Pakes (1986); } \\
\text { Reitzig (2003); } \\
\text { Schankerman and Pakes } \\
(1986)\end{array}$ \\
\hline $\begin{array}{l}\text { The evaluation of the correlation between patents and } \\
\text { economic growth, economic performance, and competitiveness } \\
\text { is conducted }\end{array}$ & $\begin{array}{l}\text { Atun et al. (2007); Hu and } \\
\text { Peng (2013); Schmookler } \\
\text { (1966) }\end{array}$ \\
\hline $\begin{array}{l}\text { The evaluation of the correlation between patents and national } \\
\text { and industrial technology development, as well as the } \\
\text { performance improvement is conducted }\end{array}$ & $\begin{array}{l}\text { Park and Yoon (2014); } \\
\text { Wang and Tsai (2010) }\end{array}$ \\
\hline $\begin{array}{l}\text { Correlation between patents and the knowledge economy, } \\
\text { innovative activities, and national innovative capacities is } \\
\text { determined. }\end{array}$ & $\begin{array}{l}\text { Faber and Hesen (2004); } \\
\text { Geradin et al. (2012); }\end{array}$ \\
\hline $\begin{array}{l}\text { The influence that performing technological transfer, industrial } \\
\text { cooperation, and industrial alliance through patent analysis has } \\
\text { on nations and industries is determined }\end{array}$ & $\begin{array}{l}\text { Park et al. (2012); } \\
\text { Kumazawa and } \\
\text { Gomis-Porqueras (2012) }\end{array}$ \\
\hline $\begin{array}{l}\text { The influence that protection and assurance of patent law and } \\
\text { the related activities of intellectual property right have on } \\
\text { national and industrial developments }\end{array}$ & $\begin{array}{l}\text { Iwaisako and Futagami } \\
\text { (2013); Qian (2007) }\end{array}$ \\
\hline
\end{tabular}

\section{Research Methods}

This study quantitatively analyzed and evaluated the trend, impact, and strength of research and development (R\&D) in various countries. The annual patent input and output of individual countries were firstly analyzed to construct a preliminary structure for subsequent efficiency analysis. Patent R\&D efficiency analysis was conducted through data envelopment analysis (DEA) by using data obtained from patent analysis. Finally, the analysis results were compared and examined across countries.

\subsection{Data Retrieval Strategies and Sources}

The United States is the largest commercial trading market in the world, and the development of its patent system and its patent data date back to 1975. Consequently, the US patent system is generally representative (Bass and Kurgan, 2010). Thus, this study used the patent database of the United States Patent and Trademark Office (USPTO) for patent output analysis. The patents approved and announced by the USPTO were collected to form the primary output variables. Furthermore, the input R\&D indices were derived from the World Competitiveness Online website of the International Institute for Management Development. Because of the 
limitations of sample consistency and data availability, the indices derived from the World Competitiveness Online website cover dissimilar years and countries; therefore, the data period in this study was from 2000 to 2012 . The total expenditure on R\&D and total public expenditure on education per capita were the primary input variables.

\subsection{Measurement Method for Research and Development Efficiency}

This study used DEA for patent R\&D efficiency analysis. DEA is a nonparametric method for estimating production frontiers, in which an envelope technique is used to substitute the production function in microeconomics. The basic theory of DEA is based on the concept of technical efficiency (TE) proposed by Farrell (1957). Farrell (1957) determined a production frontier to be the reference point for measuring productive efficiency; multiple outputs and inputs can be simultaneously processed. A firm's goal is assumed to be pursuing profit maximization or cost minimization. Firms that achieve productive efficiency by using the same technique form an efficiency frontier, with inefficient firms not occurring along the efficiency frontier. According to the theory proposed by Farrell (1957), Charnes, Cooper, and Rhodes (CCR) (1978) assumed constant returns to scale (CRS) and developed a relative efficiency model for multiple inputs and outputs, which is called the CCR model. The CCR model assumes that each decision-making unit (DMU) produces at an optimal scale; however, in reality, not all DMUs produce at an optimal scale. Therefore, Banker et al. (1984) modified the CRS assumption in the CCR model and proposed variable returns to scale (VRS). Specifically, TE was divided into pure technical efficiency (PTE) and scale efficiency (SE). A convexity constraint ( ) was added to the CCR model, changing the CRS assumption into the VRS assumption. The setting for the model is as follows:

$$
\begin{gathered}
\operatorname{Max}_{\theta, \lambda} \varphi \\
\text { s.t. }-\varphi q_{i}+Q \lambda \geq 0 \\
\chi_{i}-X \lambda \geq 0 \\
N 1^{\prime} \lambda=1 \\
\lambda \geq 0
\end{gathered}
$$

where $\varphi$ denotes TE, $\lambda$ represents weight vector, $Q$ is the output matrix of $M \times I$ and consists of the output vectors of $I$ DMUs, and $X$ is the input matrix of $N \times I$ and comprises the input vectors of $I$ DMUs.

\subsection{Measurement Variables}

\subsubsection{National Essential Technological Strength}

During the patent review process, to demonstrate the novelty of an invention, the patent applicant must provide patent and nonpatent literature relevant to the invention, and the patent reviewers attach the key literature, including studies they have searched for during the review process and those provided by the applicant, to the patent specification. Thus, the introduction of a patent can reflect the knowledge sources related to the patent, and the citation of a patent can reflect the influence of the patent on subsequent technology 
development. In general, a high number of citations for a patent (i.e., the total number of times that a patent is cited by subsequent patents) indicates the patent's large influence on subsequent technology development. Thus, the number of citations of a patent can be used to denote the influence of the patent technology (Chen et al., 2007; Yoshikane, 2013).

According to Karki and Krishnan (1997), when the number of citations of a patent is among the top $10 \%$ of the total number of citations in a year, the patent is called a highly cited patent. In addition, to obtain the technology influence index (TII) for a country, we should firstly calculate the proportion of the most influential patents (i.e., the top $10 \%$ of the most frequently cited patents) in the total number of patents in a country during the study period (from 2000 to 2012), as well as the proportion of the most influential patents in the total number of patents worldwide. The ratio of the first proportion to the second proportion is the TII of a country for the study period. The measurement of TII focuses on the patents with the highest number of citations. A TII value larger than 1 indicates that the patents in a country are highly influential.

In this study, the current influence of patents was measured using the current impact index (CII) developed by CHI Research (CHI Research, 1999). The CII is defined as the average frequency with which a patent issued in the previous five years in a country is cited by the patents issued in the current year, relative to the frequency with which all patents are cited. To calculate the CII, the proportion of patents issued in the previous $a$ years and cited by patents issued in year $t$ in country $i$ is first calculated $\left(M_{t-a}^{i}\right)$; then, $M_{t-a}^{i}$ is divided by the proportion of patents cited in a country in year $t\left(A_{t-a}\right)$ to produce $I_{t-a}$. The number of patents issued in country $i$ in each of the previous five years is divided by the total number of patents during the five years to obtain the weight for each year $\left(I_{t-1}, \ldots, I_{t-5}\right) . I_{t-a}$ is multiplied by the weight for each year to generate the weighted average of the number of patents in country $i$ in the previous five years. Thus, the CII for country $i$ in the previous five years $\left(\mathrm{CII}_{5}^{i}\right)$ is obtained. The equations for calculating the CII are as follows:

$$
\begin{gathered}
M_{t-a}^{i}=C_{t-a}^{i} / P_{t-a}^{i}, A_{t-a}=C_{t-a} / P_{t-a}, I_{t-a}=M_{t-a}^{i} / A_{t-a} \quad \mathrm{a}=1, \ldots, 5 \\
C I I_{a}^{i}=\sum_{a=1}^{5} I_{t-a}\left(P_{t-a}^{i} / \sum_{a=1}^{5} P_{t-a}^{i}\right)
\end{gathered}
$$

Typically, the expected CII value is 1 . If the CII value for a country is 1.10 , the value signifies that the frequency with which the patents in the country are cited is higher than the average frequency of $10 \%$. In other words, a large CII value indicates the large influence of a country's patents from the previous five years on current patents.

The CII is a relative value of the average citation frequency, and the TII only targets the patents that are most frequently cited. This study further calculated technology strength (TS) for an overall evaluation of patents and innovation (Chen et al., 2007). The equation for TS is as follows:

$$
T S_{i}=P_{i} \times C I I_{i}
$$


where $P_{i}$ is the total number of patents owned by country $i, T S_{i}$ is the TS of country $i$, and $\mathrm{CII}_{i}$ is the CII value of country $i$. Chen et al. (2007) regarded the top $25 \%$ of the most frequently cited patents as essential patents, patents which are of considerable importance. The threshold of $25 \%$ was derived from quantile calculation in statistics; the top $25 \%$ threshold may form a crucial patent level. However, the threshold defining this crucial patent level may vary according to various objectives; for example, a threshold of top $10 \%$ or smaller could be more selective. Thus, this study used $10 \%$, a relatively strict threshold, for selecting essential patents. The essential patent index (EPI) is calculated using the following equation:

$$
E P I_{i}=\frac{E P N_{i} / P_{i}}{0.10}
$$

where $E P N_{i}$ indicates the number of essential patents owned by country $i$ and $P_{i}$ denotes the total number of patents owned by country $i$. In addition, this study used essential technological strength (ETS) for evaluating national innovative competitiveness. ETS is generated using CII and EPI values. Compared with TS, the EPI can be used to more accurately assess national innovation strength (Chen et al., 2007). ETS is calculated using the following equation:

$$
E T S_{i}=P_{i} \times E P I_{i} \times C I I_{i}
$$

where $P_{i}, E P I_{i}$, and $C I I_{i}$ signify the number of patents and the EPI and CII values of country $i$, respectively.

\subsubsection{Research and Development Input}

This study adopted total expenditure on $R \& D$ and total public expenditure on education per capita as the input variables, which are regarded as the infrastructure for a country's competitiveness by the World Competitiveness Yearbook (International Institute for Management Development, 2014). In the European Commission Innovation Union Scoreboard (2014), R\&D expenditure and education are also considered crucial elements for facilitating innovation. Arundel and Kabla (1998), Faber and Hesen (2004), and Radosevic (2004) all used R\&D expenditure and education as crucial input variables. Thus, based on previous studies and international indices, this study adopted total expenditure on R\&D and total public expenditure on education per capita as the R\&D input variables.

\section{Results}

\subsection{Patent Retrieval Results}

Figure 1 and 2 show the number and percentage of patents approved in the top 10 patent-registering countries from 2000 to 2012 according to USPTO data. 
Number of patents

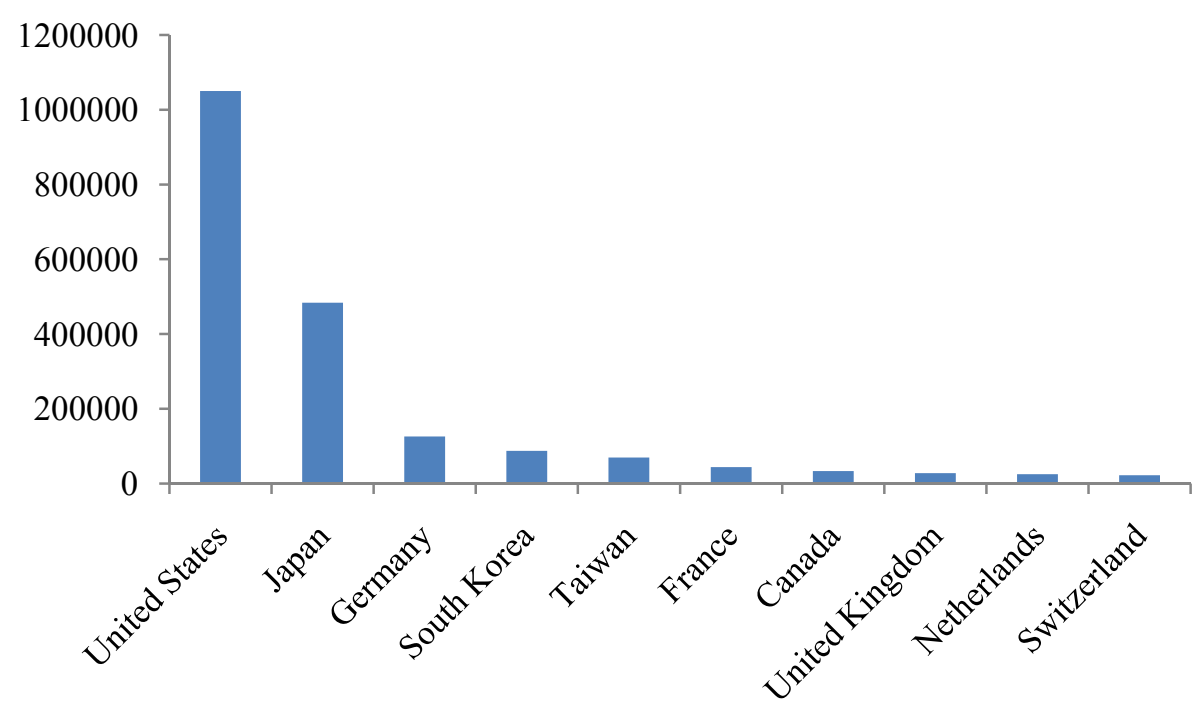

Figure 1. Number of Patents Approved in the Top 10 Patent-registering Countries

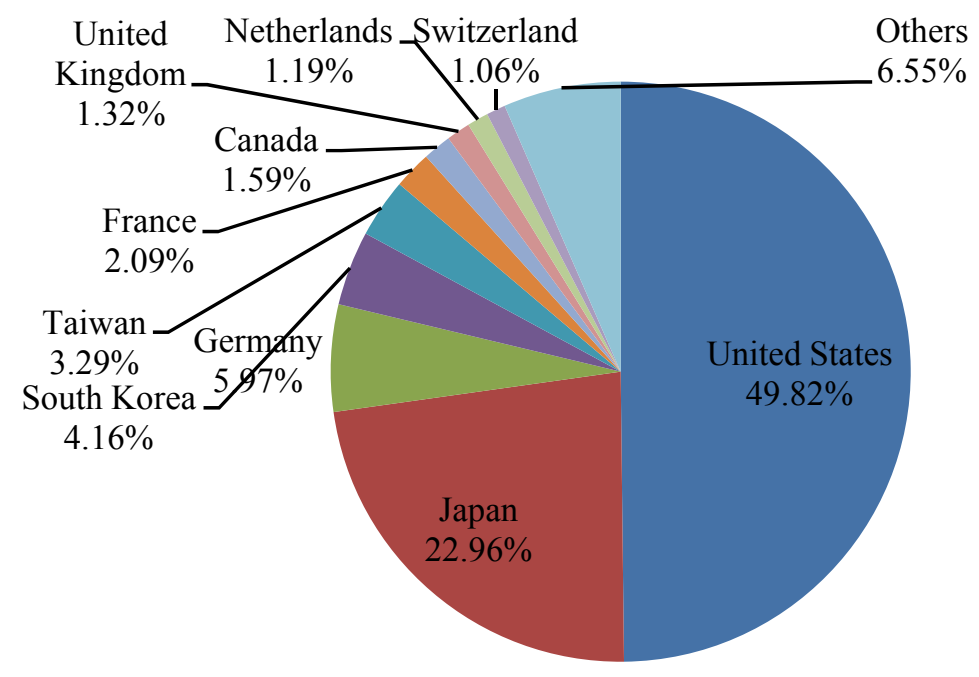

Figure 2. Percentage of Patents Approved in the Top 10 Patent-registering Countries

According to Figures 1 and 2, patents approved in the top 10 patent-registering countries accounted for approximately $93.45 \%$ of the total number of patents worldwide. Specifically, the percentage of patents registered in the United States, Japan, Germany, South Korea, Taiwan, France, Canada, the United Kingdom, the Netherlands, and Switzerland was 49.82\%, $22.96 \%, 5.97 \%, 4.16 \%, 3.29 \%, 2.09 \%, 1.59 \%, 1.32 \%, 1.19 \%$, and $1.06 \%$, respectively. These percentages indicate that most patents (more than $90 \%$ of total patents) are owned by the top 10 countries, manifesting that global science and technology development is concentrated in specific regions. Patents approved by other countries only accounted for $6.55 \%$ of total patents worldwide. If a sampling of the top 20 patent-registering countries had been used for the analysis, the percentage of patents accounted by the countries would have increased to 


\section{Al Macrothink}

Journal of Management Research

ISSN 1941-899X

2015, Vol. 7, No. 4

$98.35 \%$, an adequately representative sampling. Thus, this study used the top 20 patent-registering countries as the analysis sample for understanding the trend of patent development in various countries.

\subsection{Efficiency Analysis}

For the efficiency analysis, the national ETS for the top 20 patent-registering countries was calculated using the various indices (Table 2).

Table 2. National essential technological strength

\begin{tabular}{ccccc}
\hline Country & CII & TS & EPI & ETS \\
\hline Austria & 0.67 & 2749.99 & 0.34 & 922.46 \\
Australia & 0.90 & 10429.00 & 0.96 & 10034.31 \\
Belgium & 0.61 & 3626.39 & 0.48 & 1732.04 \\
Canada & 1.08 & 36212.85 & 1.29 & 46551.99 \\
Switzerland & 0.77 & 17200.68 & 0.57 & 9718.81 \\
China & 0.88 & 10257.91 & 0.10 & 1001.20 \\
Germany & 0.68 & 85801.14 & 0.46 & 39672.14 \\
Denmark & 0.87 & 4752.84 & 0.70 & 3303.37 \\
Finland & 1.03 & 13237.19 & 1.08 & 14257.18 \\
France & 0.64 & 28437.44 & 0.50 & 14180.67 \\
United & 0.81 & 22422.67 & 0.81 & 18223.25 \\
Kingdom & 1.09 & 11237.55 & 1.34 & 15049.80 \\
Israel & 8996.04 & 0.34 & 3096.05 \\
Italy & 0.58 & 395350.37 & 0.69 & 274339.13 \\
Japan & 0.82 & 65756.16 & 0.44 & 28758.24 \\
South Korea & 0.75 & 20286.41 & 0.57 & 11548.61 \\
Netherlands & 0.81 & 17754.77 & 0.97 & 17157.14 \\
Sweden & 0.90 & 6199.47 & 0.71 & 4428.19 \\
Singapore & 0.99 & 53822.58 & 0.52 & 27719.05 \\
Taiwan & 0.78 & 1163509.06 & 1.40 & 1627399.47 \\
\hline United States & 1.11 & & & \\
\hline
\end{tabular}

Note: CII, current impact index; TS, technology strength; EPI, essential patent index; ETS, essential technological strength

In this study, expenditures on national science and technology were based on limited budgets to achieve a maximum output. Therefore, the analysis model used was output oriented. Table 3 displays the efficiency analysis results for national ETS. 
Table 3. Efficiency analysis of national essential technological strength

\begin{tabular}{|c|c|c|c|c|c|c|}
\hline Country & $\mathrm{TE}$ & PTE & SE & $\begin{array}{l}\text { Returns } \\
\text { to scale }\end{array}$ & $\begin{array}{l}\text { Reference } \\
\text { countries }\end{array}$ & $\begin{array}{l}\text { Reference } \\
\text { frequency }\end{array}$ \\
\hline Austria & 0.02 & 0.04 & 0.71 & IRS & $\begin{array}{l}\text { Singapore and } \\
\text { United States }\end{array}$ & 0 \\
\hline Australia & 0.14 & 0.16 & 0.85 & IRS & $\begin{array}{l}\text { Singapore and } \\
\text { United States }\end{array}$ & 0 \\
\hline Belgium & 0.05 & 0.07 & 0.68 & IRS & $\begin{array}{l}\text { Singapore and } \\
\text { United States }\end{array}$ & 0 \\
\hline Canada & 0.43 & 0.48 & 0.90 & IRS & $\begin{array}{l}\text { Singapore and } \\
\text { United States }\end{array}$ & 0 \\
\hline Switzerland & 0.19 & 0.25 & 0.78 & IRS & $\begin{array}{l}\text { Singapore and } \\
\text { United States }\end{array}$ & 0 \\
\hline China & 0.02 & 1.00 & 0.02 & IRS & China & 2 \\
\hline Germany & 0.11 & 0.12 & 0.97 & IRS & $\begin{array}{l}\text { Singapore and } \\
\text { United States }\end{array}$ & 0 \\
\hline Denmark & 0.10 & 0.14 & 0.68 & IRS & $\begin{array}{l}\text { Singapore and } \\
\text { United States }\end{array}$ & 0 \\
\hline Finland & 0.42 & 0.62 & 0.67 & IRS & $\begin{array}{l}\text { Singapore and } \\
\text { United States }\end{array}$ & 0 \\
\hline France & 0.06 & 0.07 & 0.96 & IRS & $\begin{array}{l}\text { Singapore and } \\
\text { United States }\end{array}$ & 0 \\
\hline $\begin{array}{c}\text { United } \\
\text { Kingdom }\end{array}$ & 0.10 & 0.11 & 0.94 & IRS & $\begin{array}{l}\text { United States and } \\
\text { Singapore }\end{array}$ & 0 \\
\hline Israel & 0.44 & 0.66 & 0.67 & IRS & $\begin{array}{l}\text { Singapore and } \\
\text { United States }\end{array}$ & 0 \\
\hline Italy & 0.03 & 0.04 & 0.89 & IRS & $\begin{array}{l}\text { Singapore and } \\
\text { United States }\end{array}$ & 0 \\
\hline Japan & 0.38 & 0.41 & 0.93 & IRS & $\begin{array}{c}\text { United States, } \\
\text { Taiwan, and } \\
\text { China }\end{array}$ & 0 \\
\hline $\begin{array}{l}\text { South } \\
\text { Korea }\end{array}$ & 0.24 & 0.36 & 0.66 & IRS & $\begin{array}{c}\text { United States, } \\
\text { Taiwan, and } \\
\text { China }\end{array}$ & 0 \\
\hline Netherlands & 0.20 & 0.25 & 0.81 & IRS & $\begin{array}{l}\text { Singapore and } \\
\text { United States }\end{array}$ & 0 \\
\hline Sweden & 0.25 & 0.30 & 0.84 & IRS & $\begin{array}{l}\text { Singapore and } \\
\text { United States }\end{array}$ & 0 \\
\hline Singapore & 0.28 & 1.00 & 0.28 & IRS & Singapore & 14 \\
\hline Taiwan & 0.63 & 1.00 & 0.63 & IRS & Taiwan & 2 \\
\hline $\begin{array}{l}\text { United } \\
\text { States }\end{array}$ & 1.00 & 1.00 & 1.00 & - & United States & 16 \\
\hline Average & 0.26 & 0.40 & 0.74 & & & \\
\hline
\end{tabular}




\section{Macrothink}

Journal of Management Research

ISSN 1941-899X

2015, Vol. 7, No. 4

Note: The input variables are the total expenditure on $R \& D$ and total public expenditure on education per capita; the data source is the World Competitiveness Online database (2000-2012). The output variable is ETS. IRS denotes increasing returns to scale. Missing values were all excluded.

As shown in Table 3, the TE, PTE, and SE values for the United States were all 1, suggesting that the United States is a robustly efficient unit, a country with relatively high efficiency. The purpose of the reference analysis was to examine which DMUs with high efficiency could be referenced by those with low efficiency to determine the frequency with which they are referenced and evaluate which countries could serve as benchmarks for efficiency improvement. If a country is referenced by other countries numerous times, this value would indicate that the country is efficient and robust and could therefore serve as a benchmark for improvement. In addition, all of the top 20 patent-registering countries showed increasing returns to scale, indicating that resource input could be continuously increased.

\subsection{Intertemporal Efficiency Analysis}

This study used the Malmquist productivity index for analyzing changes in intertemporal efficiency and total factor productivity (Färe et al., 1992), thereby observing the dynamic development of patent performance of various countries. This study referred to technological advance as the outward movement of the efficiency frontier; process innovation, which is the production behavior of a firm, can be regarded as a type of technological advance. In terms of ETS, technological advance may be considered as an advance in the overall operating mechanism, which results in the achievement of essential technologies with the same resources. In this study, 2006 was the point dividing the period between 2000 and 2012 into 2000-2005 and 2006-2012. The results of the intertemporal efficiency analysis are shown in Table 4. 
Table 4. Dynamic productivity index analysis for the ETS of various countries

\begin{tabular}{|c|c|c|c|c|c|}
\hline & $\begin{array}{c}\text { Efficiency } \\
\text { change (EC) }\end{array}$ & $\begin{array}{c}\text { Technology } \\
\text { change } \\
\text { (TC) }\end{array}$ & $\begin{array}{c}\text { Pure } \\
\text { technical } \\
\text { efficiency } \\
\text { change (PEC) }\end{array}$ & $\begin{array}{c}\text { Scale } \\
\text { efficiency } \\
\text { change } \\
\text { (SEC) }\end{array}$ & $\begin{array}{c}\text { Total factor } \\
\text { productivity } \\
\text { change } \\
\text { (TFPC) }\end{array}$ \\
\hline Austria & 1.01 & 1.06 & 0.86 & 1.17 & 1.07 \\
\hline Australia & 0.93 & 1.06 & 0.82 & 1.14 & 0.99 \\
\hline Belgium & 0.93 & 1.06 & 0.85 & 1.10 & 0.99 \\
\hline Canada & 0.84 & 1.06 & 0.81 & 1.03 & 0.89 \\
\hline Switzerland & 1.16 & 1.06 & 1.45 & 0.80 & 1.22 \\
\hline China & 9.80 & 1.25 & 1.00 & 9.80 & 12.21 \\
\hline Germany & 1.26 & 1.06 & 1.25 & 1.01 & 1.34 \\
\hline Denmark & 0.79 & 1.06 & 0.71 & 1.12 & 0.84 \\
\hline Finland & 1.14 & 1.06 & 1.03 & 1.11 & 1.21 \\
\hline France & 0.89 & 1.06 & 0.87 & 1.01 & 0.94 \\
\hline $\begin{array}{l}\text { United } \\
\text { Kingdom }\end{array}$ & 0.94 & 1.06 & 0.93 & 1.01 & 1.00 \\
\hline Israel & 0.80 & 1.06 & 0.74 & 1.09 & 0.85 \\
\hline Italy & 1.28 & 1.06 & 1.23 & 1.04 & 1.36 \\
\hline Japan & 1.55 & 1.07 & 1.68 & 0.92 & 1.66 \\
\hline $\begin{array}{l}\text { South } \\
\text { Korea }\end{array}$ & 1.48 & 1.06 & 1.05 & 1.41 & 1.57 \\
\hline Netherlands & 1.63 & 1.06 & 1.53 & 1.06 & 1.73 \\
\hline Sweden & 0.83 & 1.06 & 0.80 & 1.03 & 0.88 \\
\hline Singapore & 1.71 & 1.06 & 1.00 & 1.71 & 1.81 \\
\hline Taiwan & 1.82 & 1.06 & 1.00 & 1.82 & 1.93 \\
\hline $\begin{array}{l}\text { United } \\
\text { States }\end{array}$ & 1.00 & 1.15 & 1.00 & 1.00 & 1.15 \\
\hline Average & 1.24 & 1.07 & 1.00 & 1.24 & 1.34 \\
\hline
\end{tabular}

As shown in Table 4, the total factor productivity for the ETS of the countries increased during the first half of the studied period (2000-2005) compared to the second half (2006-2012) (average TFPC $=1.34)$. In particular, China showed the highest increase in total factor productivity $($ TFPC $=12.21)$, demonstrating China's emphasis on and efforts to enhance its patent technologies. Regarding EC, the efficiency values for China $(\mathrm{EC}=9.80)$, Taiwan $(\mathrm{EC}=1.82)$, and Singapore $(\mathrm{EC}=1.71)$ exhibited the greatest increases, suggesting that resource allocations and decisions were adequate to enable efficiency improvement. Moreover, the overall TC value was higher for the countries in 2006-2012 than for those in 2000-2005, and the increases shown by China $(\mathrm{TC}=1.25)$ and the United States $(\mathrm{TC}=1.15)$ were relatively substantial.

\section{Conclusion and Recommendations}

This study compiled R\&D efficiency values for the world's top patent-registering countries by analyzing patent approval figures, national ETS, and efficiency; the results can serve as a 
reference for governments in formulating patent R\&D strategies. Previous studies assessing technological R\&D efficiency have mostly used quantitative patent-related indices; however, these conventional quantitative indices have been criticized for only focusing on the quantity of patents and ignoring the influence of individual patent. Thus, based on the concept of essential patents, this study used national ETS to assess R\&D efficiency values for each country and sought to provide an objective assessment mechanism.

The results showed that the TE, PTE, and SE values for the United States were all 1, indicating that the United States is located on the efficiency frontier and is therefore a highly efficient country. Except for China, Singapore, Taiwan, and the United States with PTE values of 1 , other countries showed PTE values lower than 1, indicating that these countries may exhibit poor management or incorrect decisions and should therefore reexamine their resource allocations. Except for the United States, all of the countries had increasing returns to scale, suggesting that most countries could increase input to enhance ETS. Overall, most countries could benefit from continued efficiency improvement and also exhibited problems related to poor SE, which could be improved by increasing R\&D funding and education expenditures.

In the intertemporal efficiency analysis, the dynamic productivity index analysis showed the overall efficiency and technology growth of the top 20 patent-registering countries (Table 4), demonstrating that these countries have increased their emphasis on patent technologies in recent years. In particular, the TFPC value of China increased considerably in the studied period, indicating that the quantity and influence of patents in China have increased substantially since 2006. In addition, the ETS values for Italy (TFPC $=1.36)$, Japan (TFPC = $1.66)$, South Korea $(\mathrm{TFPC}=1.57)$, the Netherlands $(\mathrm{TFPC}=1.77)$, Singapore $(\mathrm{TFPC}=1.81)$, and Taiwan (TFPC $=1.93)$ improved from the first half of the studied period (2000-2005) to the second half $(2006-2010)$, displaying above-average $($ TFPC $=1.34)$ improvement. Four of these six countries are in Asia, suggesting that patent technology growth was greater in Asian countries than in Western countries during the studied period.

Regarding study limitations and recommended research, this study directly used secondary data from the USPTO database and relative yearbooks as the input and output variables for an efficiency analysis; in other words, the analysis was conducted using objective data. However, it is difficult to measure the patent cost. Hence, R\&D efficiency among patents is hard to compare. This study used only total expenditure on R\&D and total public expenditure on education per capita as the input indices. Therefore, future studies could identify other crucial indices through expert interviews or the Delphi method for perfecting the analysis. Furthermore, this study conducted the efficiency analysis with the aim of comparing ETS values across various countries; however, whereas the efficiency analysis was completed, the exogenous variables that may have influenced efficiency values were not investigated because of limitations of secondary data. Future studies could supplement this part of the research. Finally, this study primarily used data from the USPTO database. However, patent data are region specific; the application and influence of patents in the European Patent Office (EPO) may differ from those in the USPTO. Thus, future scholars could compare data differences across various patent offices. 


\section{Acknowledgement}

This work was supported by the Ministry of Science and Technology of Taiwan [MOST 103-2410-H-492-002].

\section{References}

Arundel, A., \& Kabla, I. (1998). What Percentage of Innovations are Patented? Empirical Estimates for European Firms. Research Policy, 27(2), 127-141. http://dx.doi.org/10.1016/S0048-7333(98)00033-X

Atun, R. A., Harvey, I., \& Wild, J. (2007). Innovation, Patents and Economic Growth. International Journal of Innovation Management, 11(2), 279-297. http://dx.doi.org/10.1142/S1363919607001758

Banker, R. D., Charnes, A., \& Cooper, W. W. (1984). Some Models for Estimating Technical and Scale Inefficiencies in Data Envelopment Analysis. Management Science, 30(9), 1078-1092. http://dx.doi.org/10.1287/mnsc.30.9.1078

Bass, S. D., \& Kurgan, L. A. (2010). Discovery of Factors Influencing Patent Value Based on Machine Learning in Patents in the Field of Nanotechnology. Scientometrics, 82(2), 217-241. http://dx.doi.org/10.1007/s11192-009-0008-z

Charnes, A., Cooper, W. W., \& Rhodes, E. (1978). Measuring the Efficiency of Decision Making Units. European Journal of Operational Research, 2(6), 429-444. http://dx.doi.org/10.1016/0377-2217(78)90138-8

Chen, D. Z., Lin, W. Y. C., \& Huang, M. H. (2007). Using Essential Patent Index and Essential Technological Strength to Evaluate Industrial Technological Innovation Competitiveness. Scientometrics, 71(1), 101-116. http://dx.doi.org/10.1007/s11192-007-1655-6

Chen, Y. S., Shih, C. Y., \& Chang, C. H. (2013). Patents and Market Value in the U.S. Pharmaceutical Industry: New Evidence from Panel Threshold Regression. Scientometrics, 97(2), 161-176. http://dx.doi.org/10.1007/s11192-013-0999-3

Cheng, Y. H., Kuan, F. Y., Chuang, S. C., \& Ken, Y. (2010). Profitability Decided by Patent Quality? An Empirical Study of the U.S. Semiconductor Industry. Scientometrics, 82(1), 175-183. http://dx.doi.org/10.1007/s11192-009-0080-4

CHI Research (1999). Tech-Line background paper. [Online] Available: http://citeseerx.ist.psu.edu/viewdoc/download?doi=10.1.1.23.4124\&rep=rep1\&type=pdf (April 9, 2014).

Ernst, H. (1995). Patenting Strategies in the German Mechanical Engineering Industry and their Relationship to Firm Performance. Technovation, 15(4), 225-240. http://dx.doi.org/10.1016/0166-4972(95)96605-S

European Commission (2014). Innovation union scoreboard 2014. Brussels, Belgium: European Commission.

Faber, J., \& Hesen, A. B. (2004). Innovation Capabilities of European Nations: Cross-national Analyses of Patents and Sales of Product Innovations. Research Policy, 33(2), 193-207. http://dx.doi.org/10.1016/S0048-7333(03)00122-7 
Färe, R., Grosskopf, S., Lindgren, B., \& Roos, P. (1992). Productivity Change in Swedish Pharmacies1980-1989: A Nonparametric Malmquist Approach. Journal of Productivity Analysis, 3(1-2), 85-102. http://dx.doi.org/10.1016/0925-5273(94)00063-G

Farrell, M. J. (1957). The Measurement of Productivity Efficiency. Journal of the Royal Statistical Society, 120(3), 253-290. http://dx.doi.org/10.2307/2343100

Fung, M. K. (2005). Are Knowledge Spillovers Driving the Convergence of Productivity $\begin{array}{llll}\text { among } \quad \text { Firms? } & \text { 287-305. }\end{array}$ http://dx.doi.org/10.1111/j.0013-0427.2005.00415.x

Geradin, D., Layne-Farrar, A., \& Padilla, A. J. (2012). Elves or Trolls? The Role of Nonpracticing Patent Owners in the Innovation Economy. Industrial and Corporate Change, 21(1), 73-94. http://dx.doi.org/10.1093/icc/dtr031

Griliches, Z. (1990). Patent Statistics as Economic Indicators: A Survey. Journal of Economic Literature, 28(5), 1661-1707.

Hall, B. H., Griliches, Z., \& Hausman, J. (1986). Patent and R and D: Is There a Lag? International Economic Review, 27(2), 265-283. http://dx.doi.org/10.2307/2526504

Hall, B. H., Jaffe, A., \& Trajtenberg, M. (2005). Market Value and Patent Citations. RAND Journal of Economics, 36(1), 16-38.

Holgersson, M. (2013). Patent Management in Entrepreneurial SMEs: A Literature Review and an Empirical Study of Innovation Appropriation, Patent Propensity, and Motives. R\&D Management, 43(1), 21-36. http://dx.doi.org/10.1111/j.1467-9310.2012.00700.x

Hu, A. G. Z., \& Png, I. P. L. (2013). Patent Rights and Economic Growth: Evidence from Cross-country Panels of Manufacturing Industries. Oxford Economic Papers, 65(3), 675-698. http://dx.doi.org/10.1093/oep/gpt011

International Institute for Management Development (2014). World competitiveness yearbook. Lausanne, Switzerland: IMD World Competitiveness Center (WCC).

Iwaisako, T., \& Futagami, K. (2013). Patent Protection, Capital Accumulation, and Economic Growth. Economic Theory, 52(2), 631-668. http://dx.doi.org/10.1007/s00199-011-0658-y

Karki, M. M. S., \& Krishnan, K. S. (1997). Patent Citation Analysis: A Policy Analysis Tool. World Patent Information, 19(4), 269-272. http://dx.doi.org/10.1016/S0172-2190(97)00033-1

Kumazawa, R., \& Gomis-Porqueras, P. (2012). An Empirical Analysis of Patents Flows and R\&D Flows around the World. Applied Economics, 44(34-36), 4755-4763. http://dx.doi.org/10.1080/00036846.2010.528375

Laitner, J., \& Stolyarov, D. (2013). Derivative Ideas and the Value of Intangible Assets Derivative Ideas and the Value of Intangible Assets. International Economic Review, 54(1), 59-95. http://dx.doi.org/10.1111/j.1468-2354.2012.00726.x

Lanjouw, J. O., \& Schankerman, M. (2004). Patent Quality and Research Productivity: Measuring Innovation with Multiple Indicators. Economic Journal, 114(495), 441-465. http://dx.doi.org/10.1111/j.1468-0297.2004.00216.x

Lei, X. P., Zhao, Z. Y., Zhang, X., Chen, D. Z., Huang, M. H., Zheng, J., Liu, R. S., Zhang, J., Zhao, Y. H. (2013). Technological Collaboration Patterns in Solar Cell Industry Based on 
Patent Inventors and Assignees Analysis. Scientometrics, 96(2), 427-441. http://dx.doi.org/10.1007/s11192-012-0944-x

Narin, F. (1995). Patent as Indicators for the Evaluation of Industrial Research Output. Scientomertics, 34(3), 489-496. http://dx.doi.org/10.1007/BF02018015

Narin, F., Hamilton, K., \& Olivastro, D. (1997). The Increasing Linkage between US Technology and Public science. Research Policy, 26(3), 317-330. http://dx.doi.org/10.1016/S0048-7333(97)00013-9

OECD (1994). The measurement of scientific and technological activities: Using patent data as science and technology indicators-patent manual 1994. Paris, France: OECD.

OECD (2009). OECD patent statistics manual 2009. Paris, France: OECD.

Pakes, A. (1986). Patents as Options: Some Estimates of the Value of Holding European Patent Stocks. Econometrica, 54(4), 755-784. http://dx.doi.org/10.2307/1912835

Park, Y., Lee, S., \& Lee, S. (2012). Patent Analysis for Promoting Technology Transfer in Multi-technology Industries: The Korean Aerospace Industry Case. Journal of Technology Transfer, 37(3), 355-374. http://dx.doi.org/10.1007/s10961-010-9181-8

Park, H., \& Yoon, J. (2014). Assessing Coreness and Intermediarity of Technology Sectors Using Patent Co-classification Analysis: The Case of Korean National R\&D. Scientometrics, 98(2), 853-890. http://dx.doi.org/10.1007/s11192-013-1109-2

Qian, Yi. (2007). Do National Patent Laws Stimulate Domestic Innovation in a Global Patenting Environment? A Cross-country Analysis of Pharmaceutical Patent Protection, 1978-2002. Review of Economics and Statistics, 89(3), 436-453. http://dx.doi.org/10.1162/rest.89.3.436

Radosevic, S. (2004). A Two-tier or Multi-tier Europe? Assessing the Innovation Capacities of Central and East European Countries in the Enlarged EU. Journal of Common Market Studies, 42(3), 641-666. http://dx.doi.org/10.1111/j.0021-9886.2004.00522.x

Reitzig, M. (2003). What Determines Patent Value-insights from the Semiconductor Industry. Research Policy, 32(1), 13-26. http://dx.doi.org/10.1016/S0048-7333(01)00193-7

Schankerman, M., \& Pakes, A. (1986). Estimates of the Value of Patent Rights in Europen Countries during the Post-1950 Period. The Economic Journal, 96(384), 1052-1076. http://dx.doi.org/10.2307/2233173

Schmoch, U. (1999). Impact of International Patent Applications on Patent Indicators. Research Evaluation, 8(2), 119-131. http://dx.doi.org/10.3152/147154499781777540

Schmookler, J. (1966). Invention and economic growth. Cambridge, US: Harvard University Press.

Sternitzke, C. (2009). Defining Triadic Patent Families as a Measure of Technological Strength. Scientometrics, 81(1), 91-109. http://dx.doi.org/10.1007/s11192-009-1836-6

Wang, J. H., \& Tsai, C. J. (2010). National Model of Technological Catching up and Innovation: Comparing Patents of Taiwan and South Korea. Journal of Development Studies, 46(8), 1404-1423. http://dx.doi.org/10.1080/00220380903131654 
Wu, M. C., \& Tseng, C. Y. (2006). Valuation of Patent-A Real Options Perspective. Applied Economics Letters, 13(5), 313-318. http://dx.doi.org/10.1080/13504850500393477

Yoshikane, F. (2013). Multiple Regression Analysis of a Patent's Citation Frequency and Quantitative Characteristics: The Case of Japanese Patents. Scientometrics, 96(1), 365-379. http://dx.doi.org/10.1007/s11192-013-0953-4 